\title{
Rad eating disorder education for student dietitians
}

\author{
Elesa Crowley ${ }^{1,2^{*}}$, Deanne Harris ${ }^{1}$, Leanne Brown ${ }^{2}$ \\ From 2015 ANZAED Conference: Riding the Waves to Recovery \\ Surfers Paradise, Australia. 21-22 August 2015
}

Student dietitians are often very interested in developing skills in the assessment and management of clients with eating disorders. This may be difficult; clients often decline student participation in their care due to the sensitive nature of their condition. Nourishing Networks, a self-directed health professional learning program, was developed to enhance clinician knowledge and management skills for individuals with disordered eating and assist with the formation of local networks of support. This program was adapted and piloted for dietetic students attending placement at the University of Newcastle Department of Rural Health Tamworth. The aim of the program was to enhance the students', knowledge and skills in the management of eating disorders. Students were offered the opportunity to participate in the 10 week program. Results showed all students furthered their knowledge, skills and attitudes towards eating disorders and were better able to determine appropriate treatment plans. This program allowed students to gain tools for working with clients that they would not otherwise be exposed to in their undergraduate degree and associated placements. Future plans include the presentation of an Eating Disorder Interprofessional Learning Module for nursing, medical and allied health students and subsequently offering this 10 week program to these students.

\section{Authors' details}

${ }^{1}$ Hunter New England Local Health District, Newcastle, Australia. ${ }^{2} T$ The University of Newcastle Department of Rural Health, Newcastle, Australia.

Published: 23 November 2015

doi:10.1186/2050-2974-3-S1-P21

Cite this article as: Crowley et al:: Rad eating disorder education for student dietitians. Journal of Eating Disorders 2015 3(Suppl 1):P21.

\footnotetext{
* Correspondence: elesa.crowley@hnehealth.nsw.gov.au

${ }^{1}$ Hunter New England Local Health District, Newcastle, Australia

Full list of author information is available at the end of the article
}

Submit your next manuscript to BioMed Central and take full advantage of:

- Convenient online submission

- Thorough peer review

- No space constraints or color figure charges

- Immediate publication on acceptance

- Inclusion in PubMed, CAS, Scopus and Google Scholar

- Research which is freely available for redistribution

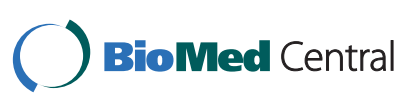

(c) 2015 Crowley et al. This is an Open Access article distributed under the terms of the Creative Commons Attribution License (http:// creativecommons.org/licenses/by/4.0), which permits unrestricted use, distribution, and reproduction in any medium, provided the original work is properly cited. The Creative Commons Public Domain Dedication waiver (http://creativecommons.org/publicdomain/ zero/1.0/) applies to the data made available in this article, unless otherwise stated. 